\title{
Autophagy and the Regulation of the Immune Response
}

\author{
Rut Valdor and Fernando Macian * \\ Department of Pathology, Albert Einstein College of Medicine, Bronx, NY
}

\section{Summary}

Autophagy is a highly conserved mechanism of lysosomal-mediated protein degradation that plays a crucial role in maintaining cellular homeostasis by recycling amino acids, reducing the amount of damaged proteins and regulating protein levels in response to extracellular signals. In the last few years specific functions for different forms of autophagy have been identified in many tissues and organs. In the Immune System, autophagy functions range from the elimination infectious agents and the modulation of the inflammatory response, to the selection of antigens for presentation and the regulation of $\mathrm{T}$ cell homeostasis and activation. Here, we review the recent advances that have allowed us to better understand why autophagy is a crucial process in the regulation of the innate and adaptive immune responses.

\section{Keywords}

Autophagy; T cell; Dendritic cell; Antigen presentation; Macrophage; Pathogen

\section{Introduction}

Autophagy was initially characterized as a cellular process responsible for the turnover of cellular components through lysosomal degradation, constituting a crucial mechanism of quality control, but also able to provide an alternative source of energy as an adaptive response to metabolic stress (e.g. starvation). A better understanding of the molecular mechanisms responsible for the activation and regulation of the different forms of autophagy and the development of accurate tools to assess autophagic activity has led in the last few years to the identification of new roles for this cellular process, including, among others, the regulation of organ development and cell differentiation, its activation as a mechanism of cell defense against biological, physical or chemical stresses, the modulation of cell death and survival and its protective effect in the aging process [1-3]. Similarly, defects in one or more forms of autophagy have been reported as causative agents in different pathologies, such as cancer, several neurodegenerative processes, myopathies and inflammatory diseases [4-6]. In this review we will explore the recent findings that have identified new functions for autophagy in the regulation of the immune system through modulation of the activity of the different cell types involved in an immune response.

Three distinctive main forms of autophagy have been described in mammalian cells and specific functions for each of these forms have been characterized in cells of the immune

\footnotetext{
(C) 2012 Elsevier Ltd. All rights reserved.

"To whom correspondence should be addressed at: Department of Pathology, Albert Einstein College of Medicine, 1300 Morris Park Avenue, Bronx, NY 10461, USA, Tel: +1 718430 2630, fernando.macian@ einstein.yu.edu.

Publisher's Disclaimer: This is a PDF file of an unedited manuscript that has been accepted for publication. As a service to our customers we are providing this early version of the manuscript. The manuscript will undergo copyediting, typesetting, and review of the resulting proof before it is published in its final citable form. Please note that during the production process errors may be discovered which could affect the content, and all legal disclaimers that apply to the journal pertain.
} 
system. Macroautophagy defines the sequestration of cytosolic components, from soluble molecules to whole organelles, inside de novo formed double-membrane vesicles termed autophagosomes, which then deliver the cargo to the lysosomes where luminal hydrolases can degrade it. A series of autophagy related proteins (Atg) have been discovered that participate in the different stages of this process, from nucleation of the limiting membrane to the elongation and sealing of the double membrane of the autophagosome, until its final fusion with the lysosome to form the autolysosome, where cargo is hydrolyzed [7]. While originally described as a non-specific form of autophagy, it has become increasingly evident that selective recognition frequently occurs to target specific molecules, organelles or even pathogens to the autophagic vacuoles. Adaptor proteins such as p62 and NBR1 play a key role in this process by recognizing ubiquitinated moieties in the substrate and interacting with the light chain 3 protein (LC3) or LC3-related proteins in the nascent autophagic vacuole [8]. While a basal macroautophagic activity appears to be present in almost all cell types, macroautophagy may also be induced in response to different stressors or activating signals. In bulk of selective degradation can also occur through microautophagy, though in this case the cargo is not sequestered in cytosolic vesicles but instead incorporated into the lysosomal lumen by invaginations of the lysosomal membrane [9].While basal microautophagy has been described in several cell types, whether this process might also be activated in response to any stimuli remains to be determined. The third form of autophagy, chaperone-mediated autophagy, exclusively targets soluble cytosolic proteins for degradation. Substrate proteins that contain a five amino acid motif biochemically related to the KFERQ pentapeptide are recognized by the heat shock cognate protein of $70 \mathrm{kD}$ (Hsc70) chaperone and delivered to a receptor at the lysosomal membrane, the lysosome-associated membrane protein type 2A (LAMP-2A). Translocation of the unfolded protein substrate occurs through a complex formed by LAMP-2A multimers, is assisted by a luminal form of Hsc70 and leads to the degradation of those proteins by lysosomal proteases. As it has been described for macroautophagy, basal activity of chaperone-mediated autophagy occurs in many cell types but a series of stimuli, including prolonged starvation and oxidative stress, lead to the upregulation of this form of autophagy $[1,10]$.

In the last few years the activity of each of these forms of autophagy have been reported in several types of immune cells, such as macrophages, dendritic cells (DCs) or lymphocytes, where they regulate different cell functions that range from the maintenance of cell homeostasis to more specific functions such as pathogen killing or antigen processing and presentation.

\section{Autophagy and the innate immune system}

\subsection{Responses to pathogens}

An active cross talk exists between autophagy and phagocytic pathways, which may be especially relevant to the innate immune responses mediated by macrophages.

Macroautophagy has been shown to participate in the defense against intracellular pathogens [11-13]. Different mechanisms have been proposed to explain how macroautophagy may enhance pathogen killing in infected or phagocytic cells (Fig. 1). Proteomic studies of latex bead-containing phagosomes isolated from macrophages demonstrated that part of the protein content of those vesicles was modulated by macroautophagy induction, indicating functional interaction between phagocytosis and autophagy [14]. Toll-like receptor engagement on murine macrophages has been shown to induce recruitment of the autophagy-associated protein LC3 to the phagosome, accelerating its maturation and enhancing fusion with lysosomes [15]. Macroautophagy seems also able to control pathogens that are replicating inside of phagosomes. For instance, Mycobacterium tuberculosis residing in phagocytic vesicles has been shown to be cleared upon macroautophagy induction, which leads to increased colocalization of autophagy proteins 
(e.g. LC3 and Beclin1) with the phagosome and increased presence of mycobacterium inside autophagosomes [16, 17]. Furthermore, mice with Atg5-deficient macrophages fail to control Mycobacterium tuberculosis infection in vivo [18]. These results indicate that macroautophagy may function to overcome the maturation block that Mycobacteria can exert on the phagosomes that contain them. Furthermore, genetic studies using siRNA screening support a of macroautophagy during Mycobacterium tuberculosis infection, since genes involved in the activation of macroautophagy were found to associate with cellular resistance against this pathogen [19]. Autophagy also plays a role in the selective elimination of intracellular pathogens in non phagocytic cells, as has been shown for pathogenic group A Streptococcus, which is enveloped by LC3+ autophagosomes in an Atg5-dependent manner and degraded by lysosome fusion [20]. Bacteria are not the only pathogens whose elimination is regulated by macroautophagy. For instance, some groups have found that the protozoan Toxoplasma gondii can also be targeted by macroautophagy, as fusion of parasitophorous vacuoles with lysosomes can be enhanced by activation of macroautophagy. Alternatively, after disruption of the parasitophorous vesicle, Toxoplasma has been shown to be engulfed in autophagosomes-like vacuoles which fuse with the lysosome to degrade the parasites [21,22]. Macroautophagy is also involved in the uptake of virions, causing their degradation and therefore limiting viral accumulation, but it has also specific roles in the regulation of viral replication, virus-induced cell death programs, viral pathogenesis and the host anti-viral immune response [23]. Morphological and biochemical studies have shown that macroautophagy can degrade Herpex simple virions and proteins, a process dependent on the protein kinase $\mathrm{R}$ and the elongation factor 2 alpha [24].

Furthermore, in a model of Sindbir virus infection of the central nervous system, the macroautopahgy adaptor protein p62 interacts with viral capsid proteins to target them for degradation in autolysosomes [25]. Macroautophagy has not only been implicated in the degradation of viral components, but also in the regulation of other aspects of the antiviral responses. For instance, macroautophagy participates in the engulfment and delivery of viral nucleic acids to endosomal Toll-like receptors (TLR), which induces an inflammatory response in plasmocytoid DCs [26], and regulates the antiviral type I interferon responses activated in infected cells [27-29]. TLR signaling is however not the only innate immune response regulated by macroautophagy and recent evidence indicates that it also modulates the inflammasome activity. Macroautophagy activation has been shown to inhibit inflammasome-mediated responses by limiting the generation of mitochondria-generated reactive oxygen species or directly targeting for degradation inflammasome components [30, $31]$.

The existence of selective poly-ubiquitination of autophagy substrates and their interaction with adaptor proteins, which present both ubiquitin-binding domains (UBA or UBZ) and LC3 interacting motifs (LIRS: WXXXL or WXXI), to target them to the inner autophagosome membrane has been well documented [32]. Adaptor/receptor proteins identified in mammalian cells include p62/sequestosome 1 [33], NBR1 [34] and NDP52 [35]. NDP52 has been shown to be implicated in macroautophagy of intracellular Salmonella typhimurium, recognizing accumulated poly-ubiquitinated proteins in the bacterial surface and recruiting Tank-Binding Kinase (TBK1) to suppress bacterial growth [35]. This kinase, which can be activated by sensing of bacterial DNA, has also been recently identified as a crucial switch required to allow targeting of Mycobacteria and maturation of the Mycobacteria-containing autophagosomes [18, 36]. The adaptor protein p62, which is a substrate of TBK1, can also bind to the surface of different bacteria, including Mycobacteria, Salmonella, Shigella and Listeria monocitogenes, to select them as cargo for macroautophagy [18, 36-39]. Interestingly, recent studies on the role of macroautophagy in Mycobacterium tuberculosis infected macrophages, have demonstrated that p62 also acts as an intermediate in the delivery of ubiquitinated proteins to the autolysosomes, where they are processed into antimicrobial peptides to enhance pathogen 
killing [40, 41]. p62 has also been found to be an adaptor intermediate in the autophagy of virus. As we have discussed above, p62 can interact with Sidbis virus capsid proteins and target them into autophagosomes, which leads to viral protein clearance and increases cell survival [25]. Recently, a new receptor protein for selective autophagy of pathogens, Optineurin, has been identified. Optineurin is phosphorylated by TBK1, which renders it capable of bridging between LC3 and ubiquitinated Salmonella, enhancing bacterial clearance. Consequently, impairment of autophagic degradation of these intracellular bacteria is seen when ubiquitin- or LC3-binding interaction-deficient mutants of Optineurin are expressed, leading to intracellular accumulation of the bacteria [42].

Given macroautophagy protective role against intracellular pathogens, it is not surprising that several infectious agents have developed virulence mechanisms that allow them to escape from the autophagic process and survive inside infected cells. Listeria monocytogenes can escape from the phagosome by making cholesterol-dependent cytolysin listeriolysin-O pores in the phagosome membrane and exiting into the cytosol where it could become a target for macroautophagy $[43,44]$. However, once in the cytosol the bacterial protein ActaA mediates recruitment of VASP and the Arp2/3 complex to the Listeria surface, which prevent ubiquitination and p62 binding and allow the bacteria to escape autophagosome engulfment [39]. Shigella can also evade autophagy by secreting the protein IcsB, which impairs the engulfment by the autophagosome by blocking the interaction between Shigella VirG and Atg5, an essential protein for autophagosome formation [45]. Also many viruses, such as those from the Herpes viridae family, have been found to develop escape strategies to inhibit autophagic defense. For instance, targeting of the initiator of macroautophagy Beclin 1 by the HSV-1 ICP34.5 protein inhibits Beclin1 and impairs macroautophagy, which results in enhanced virulence and pathogenesis of HSV-1 [46].

\subsection{Regulation of macroautophagy during the innate immune response}

TLRs were the first class of immune receptors identified as regulators of macroautophagy in cells of the innate immune system $[11,47]$. Engagement of different TLRs has been shown to induce autophagy in several cell types, including macrophages, DCs and neutrophils [17, $48,49]$. Recent studies have begun to elucidate the signaling pathways that induce autophagy following TLR engagement. The activation of the TLR-downstream signaling proteins MyD88 and Trif appears to be involved in the induction of macroautophagy. MyD88 and Trif are recruited together with Beclin-1 to TLR4, which promotes the dissociation of the Beclin1/Bcl2 complex and induces autophagosome formation [49]. Recently it has also been shown that, in the macrophage cell line RAW264.7, TLR4 stimulation activates the ubiquitin E3 ligase TRAF6, which binds Beclin-1 and ubiquitinates it at $\mathrm{Lys}_{117}$, located in the BH3 domain. This modification amplifies the TLR4-dependent activation of macroautophagy, although how ubiquitination of Beclin1 may potentiate its activity remains to be determined [50]. Interestingly, TRAF6 is also a signaling intermediary that participates in the TLR-induced MyD88-dependent activation of the IKK complex, which has recently been shown to mediate starvation-induced macroautophagy activation in an NF- $\kappa$ B-independent way in several cell lines [51]. TLRs have also been shown to promote a process involving the autophagy machinery termed LC3-associated phagocytosis. The uptake of cargo containing TLR ligands by macrophages leads to the recruitment of LC3 on the phagosome surface, promoting the degradation of the pathogens by enhancing phagosome-lysosome fusion in the absence of autophagosome formation [52]. This process suggests that LC3, which forms part of the classical macroautophagy machinery, may also have yet uncharacterized novel autophagy-independent functions. Another class of pattern recognition receptors, the Nod-like receptors (NLR), has also been implicated in the pathogen-induced activation of macroautophagy. Engagement of NOD1 and NOD2 induces 
autophagy in macrophages, likely through a process that involves recruitment of ATG16L1, one of the earliest effectors in the macroautophagy cascade, to the bacterial entry point at the plasma membrane to promote efficient autophagosome nucleation from that membrane [53]. This effect appears to be, as it has been shown for TLRs, independent of the NLR-induced activation of NFKB. Also in DCs NOD2 induces autophagosome formation contributing to efficient antigen presentation on major histocompatibility complex (MHC) II [54].

During the innate immune response, macroautophagy is also regulated by mechanisms other than activation of pattern recognition receptors. HSV-1 infection in DCs and macrophages has recently been described to trigger autophagy in a stimulator of IFN gene (STING) dependent manner [28]. Vitamin D3 can also trigger autophagy in human macrophages inhibiting HIV-1 replication through an Atg5 and Beclin-1 dependent mechanism [55]. Other immune receptors such as CD40 are also able to activate autophagy. It has been shown that CD40 stimulation in Toxopasma gondii infected human and mouse macrophages triggers colocalization of the parasite-containing vacuoles with LC3 and enhances the vacuole/lysosome fusion. This process can be inhibited through genetic or pharmacological blockade of macroautophagy [21].

Cytokines also appear to play a key role in the regulation of macroautophagy. IFN- $\gamma$ induces macroautophagy in an IFN- $\gamma$ inducible GTPase Irgm1/IRGM (murine/human)dependent manner in macrophages. Mycobacterium tuberculosis infected macrophages activate macroautophagy and show increased pathogen elimination in response to pretreatment with IFN- $\gamma[16,56]$. This effect appears to be dependent on the activation of macroautophagy since silencing the expression of Beclin-1 prevents maturation of pathogens-containing phagosomes in response to IFN- $\gamma$ [56]. Recently, lipid mediators generated by the cytosolic phospholipase A2 have also been reported to participate in the regulation of IFN $\gamma$-induced autophagy in the murine macrophage cell line RAW264.7 [57]. CCL2 and IL-6 can also upregulate autophagy in human CD11b+ peripheral blood mononuclear cells [58], while IL1 $a / \beta$ have been shown to induced autophagy in human macrophages [50]. Whereas IFN $\gamma$, the archetypical T helper (Th) 1 cytokine, induces macroautophagy in macrophages, IL4 and IL-13, classical Th2 cytokines, have been reported to inhibit autophagy in murine and human macrophages [59]. Furthermore, in Mycobacterium tuberculosis infected murine macrophages, IL-4 and IL-13 can block IFN $\gamma$ induced macroautophagy and phagosome maturation in a STAT6-dependent manner [59]. IL-10, another cytokine that can be produced by Th2 cells, inhibits starvation-induced autophagy via activation of the PI3K/Akt/mTOR pathway in murine macrophages [60].

\section{Autophagy and the adaptive immune system}

\subsection{Antigen presentation: tolerance and immunity}

One of the first functions attributed to autophagy in the regulation of the adaptive immune response was its role in the presentation of antigens by professional antigen presenting cells, including DCs, macrophages and B cells (Fig. 2). In these cells, delivery of intracellular proteins to class II loading compartments would account for the presentation of intracellular antigens on MHC class II molecules. Initial analyses of the peptides presented on MHC-II in human B cell lines revealed that starvation-mediated induction of macroautophagy caused increased presentation of peptides from cytosolic and lysosomal origin [61]. However, not only the presentation of cellular endogenous proteins was enhanced by macroautophagy, but also antigens from intracellular bacteria and virus appeared to be processed through macroautophagy to be loaded in MHC class II proteins, enhancing antigen presentation and the subsequent adaptive response against the pathogen [62-66]. As we discussed above, those pathogens can frequently be specifically targeted via several adaptor proteins, such as p62, NDP52 or Optineurin, which recognize ubiquitinated moieties in the pathogen surface 
and help recruit them to forming autophagosomes [35, 40, 42]. Alternatively, increased maturation of phagosomes can also be facilitated by the activation of macroautophagy or by the direct action of autophagy-related proteins, such as LC3 $[15,16]$. However, as suggested from the regulation by macroautophagy of the self-antigen peptidome presented in MHC class II by antigen presenting cells [61], there appears to exist a basal level of macroautophagy that continuously provides proteins to class II loading compartments [67]. These results suggest that macroautophagy may not only participate in the regulation of the immune responses to foreign antigens, but it may also be involved in the establishment of tolerance to self proteins. However, generation and presentation of citrullinated peptides, which are frequent targets of autoantibodies in several autoimmune diseases, has recently been shown to be dependent on macroautophagy in DCs and B cells, suggesting that autophagy may also contribute to the presentation of modified neo-antigens that cause a break in tolerance and lead to autoimmunity [68]. In further support of the involvement of macroautophagy in the regulation of immune homeostasis and tolerance, genome wide association studies in human populations have revealed genetic predisposition to Crohn's disease associated with single nucleotide polymorphisms in several autophagy genes including, among others, ATG16L1 and IRGM [69-72]. Studies using irradiated mice reconstituted with $\mathrm{Atg} 1611^{-/-}$fetal liver cells or cells expressing a hypomorphic mutant protein have confirmed the association of ATG16L1 and Crohn's disease [73, 74]. The exact mechanism through which ATG16L1 may regulate inflammatory bowel disease is still not clear, and may in fact be independent of the autophagy process itself, as mice expressing a hypomorphic ATG16L1 have disorganized structure and defective granule exocytosis in a population of specialized intestinal epithelial cells, Paneth cells, which are implicated in the secretion of antimicrobial proteins to maintain the intestinal homeostasis [74]. In addition, fetal liver-derived Atg16L1-deficient macrophages show a dramatic increase in the production of several cytokine and interleukin-1 $\beta$ after LPS stimulation [73]. The involvement of macroautophagy in other autoimmune disorders has also been reported. For instance, increased Atg 5 expression has been detected in peripheral $\mathrm{T}$ cells of multiple sclerosis patients [75], while genetic association of this gene with lupus has also been reported [76]. Furthermore, studies in mouse models of lupus revealed dysregulated macroautophagy, whereas administration of a the protective peptide P140 to those mice resulted in diminished autophagic flux in B cells leading to decreased autoreactive $\mathrm{T}$ cell priming $[77,78]$.

Although the precise mechanism has not yet been fully elucidated, macroautophagy has been reported to facilitate the loading of intracellular viral antigens into MHC class I molecules. In a model of murine HSV-1 infection, early loading of viral antigen on MHC class I was clearly dependent on the proteasome system, but at a later stage activation of macroautophagy was responsible for increased antigen presentation and enhanced CD8+ T cell responses [79].

Macroautophagy is however not the only form of autophagy that contributes to the presentation of antigen on MHC molecules. Modification of the levels of expression of LAMP-2A, the receptor for chaperone-mediated autophagy, led to changes in the presentation on MHC class II of antigens in a lymphoblastoid B cell line: whereas overexpression of this receptor caused increased CD4+ T cell responses to a cytosolic antigen, silencing LAMP-2A expression resulted in decreased CD4+ T cell activation [80]. Recently, a process that has the characteristics of microautophagy has been reported to occur in late endosomes in DCs [81]. This form of autophagy delivers cytosolic proteins through a process on invagination that occurs in the endosomal membrane in multivesicular bodies in an endosomal sorting complex required for transport (ESCRT)-dependent manner. In addition to in bulk engulfment of cytosolic component in those invaginations, this process has also been shown to select specific cytosolic proteins for internalization through 
interactions of the cytosolic chaperone Hsc70 with selected proteins and the endosomal membrane, which confers substrate specificity [81]. The fact that both chaperone-mediated autophagy and endosomal microautophagy share the Hsc70 chaperone and the protein substrate targeting motif opens the possibility of the latest pathway also contributing, at least in part, to the antigen presentation originally attributed to chaperone-mediated autophagy.

Although many questions still remain to be answered on how the delivery of proteins by each form of autophagy to antigen loading compartments is regulated, the nature of the proteins targeted or the role that macroautophagy, endosomal microautophagy or chaperonemediated autophagy may play in specific physiological contexts in the modulation of $\mathrm{T}$ cell responses to endogenous or exogenous antigens, it is becoming increasingly clear that all forms of autophagy described in mammalian cells participate in the processing or delivery of proteins to antigen loading compartments to be presented on MHC molecules in the cell surface. This opens, thus, the exciting possibility of targeting autophagy as a therapeutic tool to increase efficient antigen presentation and induce stronger $\mathrm{T}$ cell responses. In fact, targeted delivery of proteins achieved through the generation of LC3-fusions clearly increases antigen presentation from those proteins in DCs [12]. Furthermore, treatment with rapamycin, which by inhibiting the mammalian target of rapamycin (mTOR) 1 complex activates macroautophagy in many cell types, enhances presentation of mycobacterial antigens by DCs and increases the efficiency of vaccination achieved using BCG infected DCs in mice [82].

Interestingly, whereas different forms of autophagy contribute to antigen processing and presentation in antigen-presenting cells, the autophagic activity in antigen donor cells is also crucial for efficient antigen presentation and the priming of immune responses. Studies performed with mice immunized with influenza A virus-infected cells have shown that the activation of macroautophagy in those infected cells leads to strong MHC class I antigen presentation and increased CD8+ T cell activity. Consequently, vaccinations using Atg5deficient infected cells are much less effective [83]. This process appears to play a key role in regulating the response of the immune system against cancer cells by enhancing the presentation of tumor antigens and therefore the generation of anti-cancer immune responses. Macroautophagy activity in the tumor cells is required for chemotherapy-induced cell death to become immunogenic. This effect appears to be mediated by the regulation of ATP release, which is blocked when macroautophagy is inhibited. Consequently, cancer cells deficient in Atg5, Atg7 or Beclin1 fail to generate an effective antitumor T cell response following chemotherapy [84]. Therefore, modulation of autophagy could become an effective adjuvant therapy, as it would potentiate immune responses against tumor antigens in cancers treated with chemotherapeutic agents. In this sense, the vitamin $\mathrm{E}$ analog a-tocopheryloxyacetic acid has been reported to induce macroautophagy in several murine tumor cell lines resulting in enhanced antigen cross-presentation [85]. Similarly nanoparticle-mediated delivery of tumor antigens into autophagosomes has also been recently shown to increase cross-presentation of those antigens and cause stronger CD8+ T cell responses following vaccination [86].

The involvement of autophagy in processing and presentation of antigens is however not restricted to peripheral professional antigen presenting cells. Thymic epithelial cells also rely on macroautophagy to generate peptides presented on MHC-II [87]. As described in DCs, thymic epithelial cell show a constitutive activation of macroautophagy which feeds antigens to be loaded on MHC class II complexes, modulating positive and negative thymocyte selection. In fact, transplanted thymi defective in Atg5 fail to sustain effective selection of certain TCR-transgenic thymocytes, and animals receiving those grafts developed with time multiorgan infiltrates and colitis, underlying the role of macroautophagy in the regulation of central $\mathrm{T}$ cell tolerance [87]. 


\subsection{Regulation of $T$ cell function}

Whereas autophagy can shape $\mathrm{T}$ cell responses through its contribution to the presentation of antigens in the thymus and peripheral antigen presenting cells, recent evidence has also identified specific roles of autophagy in T and B cells themselves, regulating cell homeostasis, cell activation and cell death.

Basal macroautophagy activity has been reported in thymocytes at all stages of development ranging from double negative to single positive cells [88]. Although the exact role of macroautophagy in thymocyte development has not yet been elucidated, current studies indicate that this form of autophagy is required for thymocyte progenitor survival. Accordingly, Atg5-deficient Rag2 ${ }^{-/}$and Beclin1-deficient $R a g 1^{-/}$chimeras present greatly reduced total numbers of thymocytes $[89,90]$.

Peripheral T cells show also basal levels of macroautophagy that are upregulated in response to TCR engagement $[89,91,92]$. The regulation of this process is still not completely understood. Rapamycin treatment of $\mathrm{T}$ cells has been described to cause increased basal macroautophagy, suggesting that, as in other cell types, mTOR acts as an inhibitor of basal macroautophagy in T cells [91]. In activated Jurkat T cells, an NF- $\kappa$ B-mediated upregulation of Beclin1 expression has been described, supporting that increased expression of Beclin1 in response to TCR engagement could underlie the activation of macroautophagy that follows TCR stimulation [93]. Studies using T cell specific knock-out mice of the class III phosphpinositide-3 kinase Vps34, an essential component of the autophagy-activating complex, have yielded, however conflicting results regarding the role that the Vps34/ Beclin1 complex has in the regulation of macroautophagy in T cells [94, 95]. In one study, Vps34-deficient $T$ cells conserved macroautophagy activity but showed defect in IL7receptor expression, which led to decreased cell survival [94]. A different knock-out model revealed that Vps34 was required to activate macroautophagy in T cells, which showed accumulation of mitochondria, increased reactive oxygen species production and decreased survival [95]. It remains to be determined, thus, whether activation of macroautophagy in $\mathrm{T}$ cells in response to different stimuli or in different situations might show differential requirements for the Vps34/Beclin1-dependent canonical pathway and for non-canonical Vps34-independent pathways.

Macroautophagy is required to maintain organelle homeostasis in peripheral $\mathrm{T}$ cells. Turnover of mitochondria content during $\mathrm{T}$ cell development from thymocyte to mature $\mathrm{T}$ cells is controlled by macroautophagy, and peripheral Atg7 or Atg3 deficient T cells, unable to complete the elongation of the limiting membrane to form autophagosomes, show abnormal accumulation of mitochondria, which causes increased reactive oxygen species production in these cells [96, 97]. However mitochondria appear to be actively excluded from autophagic vacuoles in activated T cells [98]. It is likely that differences in the properties of mitochondria in quiescent and activated $\mathrm{T}$ cells or in the engagements of specific targeting mechanism may account for the differential substrate specificity exhibited by $\mathrm{T}$ cells in those two functional states. Slowing down mitochondrial turnover during activation may allow the cell to preserve these organelles, which play a crucial role in specific TCR-induced responses such as the regulation of calcium signaling [99]. Endoplasmic reticulum homeostasis is also dependent on macroautophagy in T cells, and macroautophagy-deficient $\mathrm{T}$ cells show functional defects in calcium signaling, a likely consequence of altered mobilization from the endoplasmic reticulum intracellular calcium stores [100].

Macroautophagy is a classical pathway utilized by cells in response to starvation to generate the required nutrients to survive that stress through the degradation on non-essential cell components [101]. High bioenergetic demand follows T cell activation to support activation- 
induced responses including the production and secretion of new proteins and rapid cell division. T cells deficient in Atg7 fail to increase ATP generation in response to TCR and CD28 engagement [98], which could explain the decreased proliferative responses reported in macroautophagy-deficient $\mathrm{T}$ cells $[89,98]$. The early kinetics of macroautophagy activation in $\mathrm{T}$ cells allows the possibility that macroautophagy may be required to provide for the initial burst of energy demand before increased anaerobic glycolysis can be initiated through the upregulation of the expression of glucose transporters at the plasma membrane [102].

Macroautophagy also regulates cell death and survival in T cells. Increased activation induced cell death has been reported in Atg5, Atg3 and Beclin-1 deficient T cells, which correlates with a reduced size of the peripheral $\mathrm{T}$ cell compartment in mice bearing those cells $[89,96,103]$. Several mechanisms have been proposed to explain the involvement of macroautophagy in the regulation of $\mathrm{T}$ cell survival. Altered degradation of mitochondria through this pathway or mitophagy with increased production of reactive oxygen species has been described in macroautophagy-deficient T cells [97]. An uncontrolled burst of reactive oxygen species generation following TCR engagement could account for the increased levels of cell death seen in activated macroautophagy-deficient $\mathrm{T}$ cells. Recently, a direct role of Beclin1 in the regulation of the intracellular levels of proapoptotic proteins has been proposed. Beclin1 ${ }^{-/-} \mathrm{T}$ cell show increased accumulation of caspase 3, caspase 8 and Bim, suggesting that macroautophagy may regulate the levels of these proapoptotic proteins [103]. The protective effect of macroautophagy appears to be tightly regulated. The death receptor adaptor protein FADD and caspase 8 limit macroautophagy activity during T cell activation and prevent uncontrolled autophagic activity that could result deleterious to the $\mathrm{T}$ cells [104]. The requirement for a balanced macroautophagy activation appears to be exploited by some pathogens to dysregulate macroautophagy and induced cell death. The Env protein released by the HIV-1 virus induces activation of macroautophagy in noninfected bystander T cells leading to their death [105].

Recently, a new mechanism through which macroautophagy can regulate $\mathrm{T}$ cell activation has been described. In murine Th2 and CD8+ T cells, selective macroautophagy targets Bcl10, a component of the IKK-activating complex, for degradation and contributes to the modulation of NF- $\mathrm{kB}$ activity. In those cells, TCR engagement leads to ubiquitination of Bcl10. The adaptor protein $\mathrm{p} 62$ binds then ubiquitinated $\mathrm{Bcl10}$ and recruits this protein to the autophagosome for degradation [106]. Interestingly, chaperone-mediated autophagy has also been reported to regulate NF- $\mathrm{KB}$ activation through the regulation of the basal levels of $\mathrm{I} \kappa \mathrm{B}$, although the function of this form of autophagy during $\mathrm{T}$ cell activation still remains to be defined [107].

\subsection{Autophagy in B cells}

Macroautophagic activity has also been described activated in B cells where it appears to regulate their development and function. Deletion of $\operatorname{Atg} 5$ in the B cell compartment results in decreased numbers of $B$ cell precursors and a defective pro to pre-B cell transition [108]. As in T cells, activation of autophagy in B cells also occurs following the engagement of their antigen receptor, the BCR, and is negatively regulated by CD40 signaling [109]. Interestingly, in activated B cells, the BCR has been shown to localize to autophagosomes and facilitate the recruitment of the toll-like receptor TLR9 to these structures, which results in enhanced MAPK signaling [110].

\section{Concluding remarks}

Even though we have just started to unveiled some of the specific functions that autophagy has in the different types of cells that constitute the Immune System, this catabolic process 
has revealed itself as a crucial component of the regulatory machinery that ensures the development of effective immune responses. Autophagy is involved in almost every key step from the recognition of a pathogen, to its destruction and the development of a specific adaptive immune response to it. Moreover, it also controls cell homeostasis and modulates the activation of many immune cells.

There are, however, many questions that still remain unanswered. We have only begun characterizing the complex signaling pathways that connect the engagement of immune receptors and the activation of the different forms of autophagy. Similarly, whereas most of the research carried out so far has been focused on canonical macroautophagy, we still know very little on how non-canonical forms of macroautophagy, microautophagy or chaperonemediated autophagy may regulate specific functions in distinct types of cells of the Immune System. It is also tempting to speculate that, as it seems to occur during LC3-associated phagocytosis, classical proteins of the autophagic machinery may also regulate certain functions through processes that do not involved autophagy activation. Answering these and other questions will help us better understand the mechanisms that regulate autophagy in immune cells and the precise role that this process has in the establishment of immune responses against foreign pathogens or cancer cells, or in the generation of tolerance to self antigens.

The proven importance of autophagy in key aspects of the immune response, make it an attractive target for the development of immunomodulatory therapies. While the arsenal of available drugs that can modulate autophagy is still small, the development of new more potent and specific activators or inhibitors of different forms of autophagy should become a very valuable tool to boost immune responses against pathogens or cancer cells or to downmodulate inflammatory responses during autoimmunity.

\section{Acknowledgments}

Work in our laboratory is supported by the National Institutes of Health/National Institute on Aging and the National Institute of Allergy and Infectious Diseases (to FM).

\section{Abbreviations}

$\begin{array}{ll}\text { Atg } & \text { autophagy related protein } \\ \text { DC } & \text { dendritic cells } \\ \text { Hsc70 } & \text { heat shock cognate protein of 70 kD } \\ \text { LAMP-2A } & \text { lysosome-associated membrane protein type 2A } \\ \text { LC3 } & \text { light chain 3 protein } \\ \text { MHC } & \text { major histocompatibility complex } \\ \text { NLR } & \text { Nod-like receptor } \\ \text { TCR } & \text { T cell receptor } \\ \text { Th } & \text { T helper cell } \\ \text { TLR } & \text { toll-like receptor }\end{array}$

\section{References}

1. Arias E, Cuervo AM. Chaperone-mediated autophagy in protein quality control. Curr Opin Cell Biol. 2011; 23:184-189. [PubMed: 21094035] 
2. Hubbard VM, Valdor R, Macian F, Cuervo AM. Selective autophagy in the maintenance of cellular homeostasis in aging organisms. Biogerontology. 2012; 13:21-35. [PubMed: 21461872]

3. Mizushima N, Levine B. Autophagy in mammalian development and differentiation. Nat Cell Biol. 2010; 12:823-830. [PubMed: 20811354]

4. Sridhar S, Botbol Y, Macian F, Cuervo AM. Autophagy and disease: always two sides to a problem. J Pathol. 2012; 226:255-273. [PubMed: 21990109]

5. Wong E, Cuervo AM. Autophagy gone awry in neurodegenerative diseases. Nat Neurosci. 2010; 13:805-811. [PubMed: 20581817]

6. White E. Deconvoluting the context-dependent role for autophagy in cancer. Nat Rev Cancer. 2012; 12:401-410. [PubMed: 22534666]

7. Mizushima N, Yoshimori T, Ohsumi Y. The role of Atg proteins in autophagosome formation. Annu Rev Cell Dev Biol. 2011; 27:107-132. [PubMed: 21801009]

8. Kirkin V, McEwan DG, Novak I, Dikic I. A role for ubiquitin in selective autophagy. Mol Cell. 2009; 34:259-69. [PubMed: 19450525]

9. Ahlberg J, Glaumann H. Uptake--microautophagy--and degradation of exogenous proteins by isolated rat liver lysosomes. Effects of $\mathrm{pH}$, ATP, and inhibitors of proteolysis. Exp Mol Pathol. 1985; 42:78-88. [PubMed: 3967751]

10. Cuervo AM, Dice JF. A receptor for the selective uptake and degradation of proteins by lysosomes. Science. 1996; 273:501-503. [PubMed: 8662539]

11. Deretic V. Autophagy in immunity and cell-autonomous defense against intracellular microbes. Immunol Rev. 2011; 240:92-104. [PubMed: 21349088]

12. Schmid D, Munz C. Immune surveillance of intracellular pathogens via autophagy. Cell Death Differ. 2005; 12:1519-1527. [PubMed: 16247499]

13. Yordy B, Iwasaki A. Autophagy in the control and pathogenesis of viral infection. Curr Opin Virol. 2011; 1:196-203. [PubMed: 21927636]

14. Shui W, Sheu L, Liu J, Smart B, Petzold CJ, Hsieh TY, Pitcher A, Keasling JD, Bertozzi CR. Membrane proteomics of phagosomes suggests a connection to autophagy. Proc Natl Acad Sci U S A. 2008; 105:16952-16957. [PubMed: 18971338]

15. Sanjuan MA, Dillon CP, Tait SW, Moshiach S, Dorsey F, Connell S, Komatsu M, Tanaka K, Cleveland JL, Withoff S, Green DR. Toll-like receptor signalling in macrophages links the autophagy pathway to phagocytosis. Nature. 2007; 450:1253-1257. [PubMed: 18097414]

16. Gutierrez MG, Master SS, Singh SB, Taylor GA, Colombo MI, Deretic V. Autophagy is a defense mechanism inhibiting BCG and Mycobacterium tuberculosis survival in infected macrophages. Cell. 2004; 119:753-766. [PubMed: 15607973]

17. Xu Y, Jagannath C, Liu XD, Sharafkhaneh A, Kolodziejska KE, Eissa NT. Toll-like receptor 4 is a sensor for autophagy associated with innate immunity. Immunity. 2007; 27:135-144. [PubMed: 17658277]

18. Watson RO, Manzanillo PS, Cox JS. Extracellular M. tuberculosis DNA Targets Bacteria for Autophagy by Activating the Host DNA-Sensing Pathway. Cell. 2012; 150:803-815. [PubMed: 22901810]

19. Kumar D, Nath L, Kamal MA, Varshney A, Jain A, Singh S, Rao KV. Genome-wide analysis of the host intracellular network that regulates survival of Mycobacterium tuberculosis. Cell. 2010; 140:731-743. [PubMed: 20211141]

20. Nakagawa I, Amano A, Mizushima N, Yamamoto A, Yamaguchi H, Kamimoto T, Nara A, Funao J, Nakata M, Tsuda K, Hamada S, Yoshimori T. Autophagy defends cells against invading group A Streptococcus. Science. 2004; 306:1037-1040. [PubMed: 15528445]

21. Andrade RM, Wessendarp M, Gubbels MJ, Striepen B, Subauste CS. CD40 induces macrophage anti-Toxoplasma gondii activity by triggering autophagy-dependent fusion of pathogen-containing vacuoles and lysosomes. J Clin Invest. 2006; 116:2366-2377. [PubMed: 16955139]

22. Ling YM, Shaw MH, Ayala C, Coppens I, Taylor GA, Ferguson DJ, Yap GS. Vacuolar and plasma membrane stripping and autophagic elimination of Toxoplasma gondii in primed effector macrophages. J Exp Med. 2006; 203:2063-2071. [PubMed: 16940170]

23. Lin LT, Dawson PW, Richardson CD. Viral interactions with macroautophagy: a double-edged sword. Virology. 2010; 402:1-10. [PubMed: 20413139] 
24. Talloczy Z, Virgin HWt, Levine B. PKR-dependent autophagic degradation of herpes simplex virus type 1. Autophagy. 2006; 2:24-29. [PubMed: 16874088]

25. Orvedahl A, MacPherson S, Sumpter R Jr, Talloczy Z, Zou Z, Levine B. Autophagy protects against Sindbis virus infection of the central nervous system. Cell Host Microbe. 2010; 7:115-127. [PubMed: 20159618]

26. Lee HK, Lund JM, Ramanathan B, Mizushima N, Iwasaki A. Autophagy-dependent viral recognition by plasmacytoid dendritic cells. Science. 2007; 315:1398-1401. [PubMed: 17272685]

27. Jounai N, Takeshita F, Kobiyama K, Sawano A, Miyawaki A, Xin KQ, Ishii KJ, Kawai T, Akira S, Suzuki K, Okuda K. The Atg5 Atg12 conjugate associates with innate antiviral immune responses. Proc Natl Acad Sci U S A. 2007; 104:14050-14055. [PubMed: 17709747]

28. Rasmussen SB, Horan KA, Holm CK, Stranks AJ, Mettenleiter TC, Simon AK, Jensen SB, Rixon FJ, He B, Paludan SR. Activation of Autophagy by \{alpha\}-Herpesviruses in Myeloid Cells Is Mediated by Cytoplasmic Viral DNA through a Mechanism Dependent on Stimulator of IFN Genes. J Immunol. 2011; 187:5268-76. [PubMed: 21998456]

29. Saitoh T, Fujita N, Hayashi T, Takahara K, Satoh T, Lee H, Matsunaga K, Kageyama S, Omori H, Noda T, Yamamoto N, Kawai T, Ishii K, Takeuchi O, Yoshimori T, Akira S. Atg9a controls dsDNA-driven dynamic translocation of STING and the innate immune response. Proc Natl Acad Sci U S A. 2009; 106:20842-20846. [PubMed: 19926846]

30. Nakahira K, Haspel JA, Rathinam VA, Lee SJ, Dolinay T, Lam HC, Englert JA, Rabinovitch M, Cernadas M, Kim HP, Fitzgerald KA, Ryter SW, Choi AM. Autophagy proteins regulate innate immune responses by inhibiting the release of mitochondrial DNA mediated by the NALP3 inflammasome. Nat iImmunol. 2011; 12:222-230.

31. Shi CS, Shenderov K, Huang NN, Kabat J, Abu-Asab M, Fitzgerald KA, Sher A, Kehrl JH. Activation of autophagy by inflammatory signals limits IL-1beta production by targeting ubiquitinated inflammasomes for destruction. Nat Immunol. 2012; 13:255-263. [PubMed: 22286270]

32. Kirkin V, McEwan DG, Novak I, Dikic I. A role for ubiquitin in selective autophagy. Mol Cell. 2009; 34:259-269. [PubMed: 19450525]

33. Pankiv S, Clausen TH, Lamark T, Brech A, Bruun JA, Outzen H, Overvatn A, Bjorkoy G, Johansen T. p62/SQSTM1 binds directly to Atg8/LC3 to facilitate degradation of ubiquitinated protein aggregates by autophagy. J Biol Chem. 2007; 282:24131-24145. [PubMed: 17580304]

34. Kirkin V, Lamark T, Sou YS, Bjorkoy G, Nunn JL, Bruun JA, Shvets E, McEwan DG, Clausen TH, Wild P, Bilusic I, Theurillat JP, Overvatn A, Ishii T, Elazar Z, Komatsu M, Dikic I, Johansen T. A role for NBR1 in autophagosomal degradation of ubiquitinated substrates. Mol Cell. 2009; 33:505-516. [PubMed: 19250911]

35. Thurston TL, Ryzhakov G, Bloor S, von Muhlinen N, Randow F. The TBK1 adaptor and autophagy receptor NDP52 restricts the proliferation of ubiquitin-coated bacteria. Nat Immunol. 2009; 10:1215-1221. [PubMed: 19820708]

36. Pilli M, Arko-Mensah J, Ponpuak M, Roberts E, Master S, Mandell MA, Dupont N, Ornatowski W, Jiang S, Bradfute SB, Bruun JA, Hansen TE, Johansen T, Deretic V. TBK-1 Promotes Autophagy-Mediated Antimicrobial Defense by Controlling Autophagosome Maturation. Immunity. 2012; 37:223-234. [PubMed: 22921120]

37. Zheng YT, Shahnazari S, Brech A, Lamark T, Johansen T, Brumell JH. The adaptor protein p62/ SQSTM1 targets invading bacteria to the autophagy pathway. J Immunol. 2009; 183:5909-5916. [PubMed: 19812211]

38. Dupont N, Lacas-Gervais S, Bertout J, Paz I, Freche B, Van Nhieu GT, van der Goot FG, Sansonetti PJ, Lafont F. Shigella phagocytic vacuolar membrane remnants participate in the cellular response to pathogen invasion and are regulated by autophagy. Cell Host Microbe. 2009; 6:137-149. [PubMed: 19683680]

39. Yoshikawa Y, Ogawa M, Hain T, Yoshida M, Fukumatsu M, Kim M, Mimuro H, Nakagawa I, Yanagawa T, Ishii T, Kakizuka A, Sztul E, Chakraborty T, Sasakawa C. Listeria monocytogenes ActA-mediated escape from autophagic recognition. Nat Cell Biol. 2009; 11:1233-1240. [PubMed: 19749745] 
40. Ponpuak M, Davis AS, Roberts EA, Delgado MA, Dinkins C, Zhao Z, Virgin HWt, Kyei GB, Johansen T, Vergne I, Deretic V. Delivery of cytosolic components by autophagic adaptor protein p62 endows autophagosomes with unique antimicrobial properties. Immunity. 2010; 32:329-341. [PubMed: 20206555]

41. Alonso, S.; Pethe, K.; Russell, DG.; Purdy, GE. Lysosomal killing of Mycobacterium mediated by ubiquitin-derived peptides is enhanced by autophagy. Proceedings of the National Academy of Sciences of the United States of America; 2007. p. 6031-6036.

42. Wild P, Farhan H, McEwan DG, Wagner S, Rogov VV, Brady NR, Richter B, Korac J, Waidmann O, Choudhary C, Dotsch V, Bumann D, Dikic I. Phosphorylation of the autophagy receptor optineurin restricts Salmonella growth. Science. 2011; 333:228-233. [PubMed: 21617041]

43. Py BF, Lipinski MM, Yuan J. Autophagy limits Listeria monocytogenes intracellular growth in the early phase of primary infection. Autophagy. 2007; 3:117-125. [PubMed: 17204850]

44. Meyer-Morse N, Robbins JR, Rae CS, Mochegova SN, Swanson MS, Zhao Z, Virgin HW, Portnoy D. Listeriolysin $\mathrm{O}$ is necessary and sufficient to induce autophagy during Listeria monocytogenes infection. PloS One. 2010; 5:e8610. [PubMed: 20062534]

45. Ogawa M, Yoshimori T, Suzuki T, Sagara H, Mizushima N, Sasakawa C. Escape of intracellular Shigella from autophagy. Science. 2005; 307:727-731. [PubMed: 15576571]

46. Orvedahl A, Alexander D, Talloczy Z, Sun Q, Wei Y, Zhang W, Burns D, Leib DA, Levine B. HSV-1 ICP34.5 confers neurovirulence by targeting the Beclin 1 autophagy protein. Cell Host Microbe. 2007; 1:23-35. [PubMed: 18005679]

47. Delgado MA, Deretic V. Toll-like receptors in control of immunological autophagy. Cell Death Differ. 2009; 16:976-983. [PubMed: 19444282]

48. Delgado MA, Elmaoued RA, Davis AS, Kyei G, Deretic V. Toll-like receptors control autophagy. EMBO J. 2008; 27:1110-1121. [PubMed: 18337753]

49. Shi CS, Kehrl JH. MyD88 and Trif target Beclin 1 to trigger autophagy in macrophages. J Biol Chem. 2008; 283:33175-33182. [PubMed: 18772134]

50. Shi CS, Kehrl JH. TRAF6 and A20 regulate lysine 63-linked ubiquitination of Beclin-1 to control TLR4-induced autophagy. Sci Signal. 2010; 3:ra42. [PubMed: 20501938]

51. Criollo A, Senovilla L, Authier H, Maiuri MC, Morselli E, Vitale I, Kepp O, Tasdemir E, Galluzzi L, Shen S, Tailler M, Delahaye N, Tesniere A, De Stefano D, Younes AB, Harper F, Pierron G, Lavandero S, Zitvogel L, Israel A, Baud V, Kroemer G. The IKK complex contributes to the induction of autophagy. EMBO J. 2010; 29:619-631. [PubMed: 19959994]

52. Sanjuan MA, Milasta S, Green DR. Toll-like receptor signaling in the lysosomal pathways. Immunol Rev. 2009; 227:203-220. [PubMed: 19120486]

53. Travassos LH, Carneiro LA, Ramjeet M, Hussey S, Kim YG, Magalhaes JG, Yuan L, Soares F, Chea E, Le Bourhis L, Boneca IG, Allaoui A, Jones NL, Nunez G, Girardin SE, Philpott DJ. Nod1 and Nod2 direct autophagy by recruiting ATG16L1 to the plasma membrane at the site of bacterial entry. Nat Immunol. 2010; 11:55-62. [PubMed: 19898471]

54. Cooney R, Baker J, Brain O, Danis B, Pichulik T, Allan P, Ferguson DJ, Campbell BJ, Jewell D, Simmons A. NOD2 stimulation induces autophagy in dendritic cells influencing bacterial handling and antigen presentation. Nat Med. 2010; 16:90-97. [PubMed: 19966812]

55. Campbell GR, Spector SA. Hormonally active vitamin D3 (1alpha,25-dihydroxycholecalciferol) triggers autophagy in human macrophages that inhibits HIV-1 infection. J Biol Chem. 2011; 286:18890-18902. [PubMed: 21454634]

56. Singh SB, Davis AS, Taylor GA, Deretic V. Human IRGM induces autophagy to eliminate intracellular mycobacteria. Science. 2006; 313:1438-1441. [PubMed: 16888103]

57. Qi HY, Daniels MP, Liu Y, Chen LY, Alsaaty S, Levine SJ, Shelhamer JH. A cytosolic phospholipase A2-initiated lipid mediator pathway induces autophagy in macrophages. J Immunol. 2011; 187:5286-5292. [PubMed: 22003202]

58. Roca H, Varsos ZS, Sud S, Craig MJ, Ying C, Pienta KJ. CCL2 and interleukin-6 promote survival of human CD11b+ peripheral blood mononuclear cells and induce M2-type macrophage polarization. J Biol Chem. 2009; 284:34342-34354. [PubMed: 19833726] 
59. Harris J, De Haro SA, Master SS, Keane J, Roberts EA, Delgado M, Deretic V. T helper 2 cytokines inhibit autophagic control of intracellular Mycobacterium tuberculosis. Immunity. 2007; 27:505-517. [PubMed: 17892853]

60. Park HJ, Lee SJ, Kim SH, Han J, Bae J, Kim SJ, Park CG, Chun T. IL-10 inhibits the starvation induced autophagy in macrophages via class I phosphatidylinositol 3-kinase (PI3K) pathway. Mol immunol. 2011; 48:720-727. [PubMed: 21095008]

61. Dengjel J, Schoor O, Fischer R, Reich M, Kraus M, Muller M, Kreymborg K, Altenberend F, Brandenburg J, Kalbacher H, Brock R, Driessen C, Rammensee HG, Stevanovic S. Autophagy promotes MHC class II presentation of peptides from intracellular source proteins. Proc Natl Acad Sci U S A. 2005; 102:7922-7927. [PubMed: 15894616]

62. Nimmerjahn F, Milosevic S, Behrends U, Jaffee EM, Pardoll DM, Bornkamm GW, Mautner J. Major histocompatibility complex class II-restricted presentation of a cytosolic antigen by autophagy. Eur J Immunol. 2003; 33:1250-1259. [PubMed: 12731050]

63. Paludan C, Schmid D, Landthaler M, Vockerodt M, Kube D, Tuschl T, Munz C. Endogenous MHC class II processing of a viral nuclear antigen after autophagy. Science. 2005; 307:593-596. [PubMed: 15591165]

64. Riedel A, Nimmerjahn F, Burdach S, Behrends U, Bornkamm GW, Mautner J. Endogenous presentation of a nuclear antigen on MHC class II by autophagy in the absence of CRM1-mediated nuclear export. Eur j Immunol. 2008; 38:2090-2095. [PubMed: 18624354]

65. Russmann H, Panthel K, Kohn B, Jellbauer S, Winter SE, Garbom S, Wolf-Watz H, Hoffmann S, Grauling-Halama S, Geginat G. Alternative endogenous protein processing via an autophagydependent pathway compensates for Yersinia-mediated inhibition of endosomal major histocompatibility complex class II antigen presentation. Infect Immun. 2010; 78:5138-5150. [PubMed: 20876292]

66. Lee HK, Mattei LM, Steinberg BE, Alberts P, Lee YH, Chervonsky A, Mizushima N, Grinstein S, Iwasaki A. In vivo requirement for Atg5 in antigen presentation by dendritic cells. Immunity. 2010; 32:227-239. [PubMed: 20171125]

67. Schmid D, Pypaert M, Munz C. Antigen-loading compartments for major histocompatibility complex class II molecules continuously receive input from autophagosomes. Immunity. 2007; 26:79-92. [PubMed: 17182262]

68. Ireland JM, Unanue ER. Autophagy in antigen-presenting cells results in presentation of citrullinated peptides to CD4 T cells. J Exp Med. 2011; 208:2625-2632. [PubMed: 22162830]

69. Consortium WTCC. Genome-wide association study of 14,000 cases of seven common diseases and 3,000 shared controls. Nature. 2007; 447:661-678. [PubMed: 17554300]

70. Brest P, Lapaquette P, Souidi M, Lebrigand K, Cesaro A, Vouret-Craviari V, Mari B, Barbry P, Mosnier JF, Hebuterne X, Harel-Bellan A, Mograbi B, Darfeuille-Michaud A, Hofman P. A synonymous variant in IRGM alters a binding site for miR-196 and causes deregulation of IRGMdependent xenophagy in Crohn's disease. Nat Genet. 2011; 43:242-245. [PubMed: 21278745]

71. Hampe J, Franke A, Rosenstiel P, Till A, Teuber M, Huse K, Albrecht M, Mayr G, De La Vega FM, Briggs J, Gunther S, Prescott NJ, Onnie CM, Hasler R, Sipos B, Folsch UR, Lengauer T, Platzer M, Mathew CG, Krawczak M, Schreiber S. A genome-wide association scan of nonsynonymous SNPs identifies a susceptibility variant for Crohn disease in ATG16L1. Nat Genet. 2007; 39:207-211. [PubMed: 17200669]

72. Rioux JD, Xavier RJ, Taylor KD, Silverberg MS, Goyette P, Huett A, Green T, Kuballa P, Barmada MM, Datta LW, Shugart YY, Griffiths AM, Targan SR, Ippoliti AF, Bernard EJ, Mei L, Nicolae DL, Regueiro M, Schumm LP, Steinhart AH, Rotter JI, Duerr RH, Cho JH, Daly MJ, Brant SR. Genome-wide association study identifies new susceptibility loci for Crohn disease and implicates autophagy in disease pathogenesis. Nat Genet. 2007; 39:596-604. [PubMed: 17435756]

73. Saitoh T, Fujita N, Jang MH, Uematsu S, Yang BG, Satoh T, Omori H, Noda T, Yamamoto N, Komatsu M, Tanaka K, Kawai T, Tsujimura T, Takeuchi O, Yoshimori T, Akira S. Loss of the autophagy protein Atg16L1 enhances endotoxin-induced IL-1beta production. Nature. 2008; 456:264-268. [PubMed: 18849965]

74. Cadwell K, Liu JY, Brown SL, Miyoshi H, Loh J, Lennerz JK, Kishi C, Kc W, Carrero JA, Hunt S, Stone CD, Brunt EM, Xavier RJ, Sleckman BP, Li E, Mizushima N, Stappenbeck TS, Virgin 
HWt. A key role for autophagy and the autophagy gene Atg1611 in mouse and human intestinal Paneth cells. Nature. 2008; 456:259-263. [PubMed: 18849966]

75. Alirezaei M, Fox HS, Flynn CT, Moore CS, Hebb AL, Frausto RF, Bhan V, Kiosses WB, Whitton JL, Robertson GS, Crocker SJ. Elevated ATG5 expression in autoimmune demyelination and multiple sclerosis. Autophagy. 2009; 5:152-158. [PubMed: 19066443]

76. Zhou XJ, Lu XL, Lv JC, Yang HZ, Qin LX, Zhao MH, Su Y, Li ZG, Zhang H. Genetic association of PRDM1-ATG5 intergenic region and autophagy with systemic lupus erythematosus in a Chinese population. Ann Rheum Dis. 2011; 70:1330-1337. [PubMed: 21622776]

77. Gros F, Arnold J, Page N, Decossas M, Korganow AS, Martin T, Muller S. Macroautophagy is deregulated in murine and human lupus T lymphocytes. Autophagy. 2012; 8:1113-23.

78. Page N, Gros F, Schall N, Decossas M, Bagnard D, Briand JP, Muller S. HSC70 blockade by the therapeutic peptide P140 affects autophagic processes and endogenous MHCII presentation in murine lupus. Ann Rheum Dis. 2011; 70:837-843. [PubMed: 21173017]

79. English L, Chemali M, Duron J, Rondeau C, Laplante A, Gingras D, Alexander D, Leib D, Norbury C, Lippe R, Desjardins M. Autophagy enhances the presentation of endogenous viral antigens on MHC class I molecules during HSV-1 infection. Nat immunol. 2009; 10:480-487. [PubMed: 19305394]

80. Zhou D, Li P, Lin Y, Lott JM, Hislop AD, Canaday DH, Brutkiewicz RR, Blum JS. Lamp-2a facilitates MHC class II presentation of cytoplasmic antigens. Immunity. 2005; 22:571-581. [PubMed: 15894275]

81. Sahu R, Kaushik S, Clement CC, Cannizzo ES, Scharf B, Follenzi A, Potolicchio I, Nieves E, Cuervo AM, Santambrogio L. Microautophagy of cytosolic proteins by late endosomes. Dev Cell. 2011; 20:131-139. [PubMed: 21238931]

82. Jagannath C, Lindsey DR, Dhandayuthapani S, Xu Y, Hunter RL Jr, Eissa NT. Autophagy enhances the efficacy of BCG vaccine by increasing peptide presentation in mouse dendritic cells. Nat Med. 2009; 15:267-276. [PubMed: 19252503]

83. Uhl M, Kepp O, Jusforgues-Saklani H, Vicencio JM, Kroemer G, Albert ML. Autophagy within the antigen donor cell facilitates efficient antigen cross-priming of virus-specific CD8+ T cells. Cell Death Differ. 2009; 16:991-1005. [PubMed: 19229247]

84. Michaud M, Martins I, Sukkurwala AQ, Adjemian S, Ma Y, Pellegatti P, Shen S, Kepp O, Scoazec M, Mignot G, Rello-Varona S, Tailler M, Menger L, Vacchelli E, Galluzzi L, Ghiringhelli F, di Virgilio F, Zitvogel L, Kroemer G. Autophagy-dependent anticancer immune responses induced by chemotherapeutic agents in mice. Science. 2011; 334:1573-1577. [PubMed: 22174255]

85. Li Y, Hahn T, Garrison K, Cui ZH, Thorburn A, Thorburn J, Hu HM, Akporiaye ET. The Vitamin E Analogue alpha-TEA Stimulates Tumor Autophagy and Enhances Antigen Cross-Presentation. Cancer Res. 2012; 72:3535-3545. [PubMed: 22745370]

86. Li H, Li Y, Jiao J, Hu HM. Alpha-alumina nanoparticles induce efficient autophagy-dependent cross-presentation and potent antitumour response. Nat Nanotech. 2011; 6:645-650.

87. Nedjic J, Aichinger M, Emmerich J, Mizushima N, Klein L. Autophagy in thymic epithelium shapes the T-cell repertoire and is essential for tolerance. Nature. 2008; 455:396-400. [PubMed: 18701890]

88. Stephenson LM, Miller BC, Ng A, Eisenberg J, Zhao Z, Cadwell K, Graham DB, Mizushima NN, Xavier R, Virgin HW, Swat W. Identification of Atg5-dependent transcriptional changes and increases in mitochondrial mass in Atg5-deficient T lymphocytes. Autophagy. 2009; 5:625-635. [PubMed: 19276668]

89. Pua HH, Dzhagalov I, Chuck M, Mizushima N, He YW. A critical role for the autophagy gene Atg5 in T cell survival and proliferation. J Exp Med. 2007; 204:25-31. [PubMed: 17190837]

90. Arsov I, Adebayo A, Kucerova-Levisohn M, Haye J, MacNeil M, Papavasiliou FN, Yue Z, Ortiz BD. A role for autophagic protein beclin 1 early in lymphocyte development. J Immunol. 2011; 186:2201-2209. [PubMed: 21239722]

91. Li C, Capan E, Zhao Y, Zhao J, Stolz D, Watkins SC, Jin S, Lu B. Autophagy is induced in CD4+ T cells and important for the growth factor-withdrawal cell death. J Immunol. 2006; 177:51635168. [PubMed: 17015701] 
92. Hubbard VM, Cadwell K. Viruses, autophagy genes, and Crohn's disease. Viruses. 2011; 3:12811311. [PubMed: 21994779]

93. Copetti T, Demarchi F, Schneider C. p65/RelA binds and activates the beclin 1 promoter. Autophagy. 2009; 5:858-859. [PubMed: 19458474]

94. McLeod IX, Zhou X, Li QJ, Wang F, He YW. The class III kinase Vps34 promotes T lymphocyte survival through regulating IL-7Ralpha surface expression. J Immunol. 2011; 187:5051-5061. [PubMed: 22021616]

95. Willinger T, Flavell RA. Canonical autophagy dependent on the class III phosphoinositide-3 kinase Vps34 is required for naive T-cell homeostasis. Proc Natl Acad Sci U S A. 2012; 109:8670-8675. [PubMed: 22592798]

96. Jia W, He YW. Temporal regulation of intracellular organelle homeostasis in T lymphocytes by autophagy. J Immunol. 2011; 186:5313-5322. [PubMed: 21421856]

97. Pua HH, Guo J, Komatsu M, He YW. Autophagy is essential for mitochondrial clearance in mature T lymphocytes. J Immunol. 2009; 182:4046-4055. [PubMed: 19299702]

98. Hubbard VM, Valdor R, Patel B, Singh R, Cuervo AM, Macian F. Macroautophagy regulates energy metabolism during effector T cell activation. J Immunol. 2010; 185:7349-7357. [PubMed: 21059894]

99. Quintana A, Schwarz EC, Schwindling C, Lipp P, Kaestner L, Hoth M. Sustained activity of calcium release-activated calcium channels requires translocation of mitochondria to the plasma membrane. J Biol Chem. 2006; 281:40302-40309. [PubMed: 17056596]

100. Jia W, Pua HH, Li QJ, He YW. Autophagy regulates endoplasmic reticulum homeostasis and calcium mobilization in T lymphocytes. J Immunol. 2011; 186:1564-1574. [PubMed: 21191072]

101. Lum JJ, Bauer DE, Kong M, Harris MH, Li C, Lindsten T, Thompson CB. Growth factor regulation of autophagy and cell survival in the absence of apoptosis. Cell. 2005; 120:237-248. [PubMed: 15680329]

102. Maciver NJ, Jacobs SR, Wieman HL, Wofford JA, Coloff JL, Rathmell JC. Glucose metabolism in lymphocytes is a regulated process with significant effects on immune cell function and survival. J Leukocyte Biol. 2008; 84:949-957. [PubMed: 18577716]

103. Kovacs JR, Li C, Yang Q, Li G, Garcia IG, Ju S, Roodman DG, Windle JJ, Zhang X, Lu B. Autophagy promotes T-cell survival through degradation of proteins of the cell death machinery. Cell Death Differ. 2012; 19:144-152. [PubMed: 21660048]

104. Bell BD, Leverrier S, Weist BM, Newton RH, Arechiga AF, Luhrs KA, Morrissette NS, Walsh CM. FADD and caspase- 8 control the outcome of autophagic signaling in proliferating T cells. Proc Natl Acad Sci U S A. 2008; 105:16677-16682. [PubMed: 18946037]

105. Espert L, Denizot M, Grimaldi M, Robert-Hebmann V, Gay B, Varbanov M, Codogno P, BiardPiechaczyk M. Autophagy is involved in T cell death after binding of HIV-1 envelope proteins to CXCR4. J Clin Invest. 2006; 116:2161-2172. [PubMed: 16886061]

106. Paul S, Kashyap AK, Jia W, He YW, Schaefer BC. Selective Autophagy of the Adaptor Protein Bcl10 Modulates T Cell Receptor Activation of NF-kappaB. Immunity. 2012; 36:947-958. [PubMed: 22658522]

107. Cuervo AM, Hu W, Lim B, Dice JF. IkappaB is a substrate for a selective pathway of lysosomal proteolysis. Mol Biol Cell. 1998; 9:1995-2010. [PubMed: 9693362]

108. Miller BC, Zhao Z, Stephenson LM, Cadwell K, Pua HH, Lee HK, Mizushima NN, Iwasaki A, He YW, Swat W, Virgin HWt. The autophagy gene ATG5 plays an essential role in B lymphocyte development. Autophagy. 2008; 4:309-314. [PubMed: 18188005]

109. Watanabe K, Ichinose S, Hayashizaki K, Tsubata T. Induction of autophagy by B cell antigen receptor stimulation and its inhibition by costimulation. Biochem Biophys Res Commun. 2008; 374:274-281. [PubMed: 18625201]

110. Chaturvedi A, Dorward D, Pierce SK. The B cell receptor governs the subcellular location of Toll-like receptor 9 leading to hyperresponses to DNA-containing antigens. Immunity. 2008; 28:799-809. [PubMed: 18513998] 


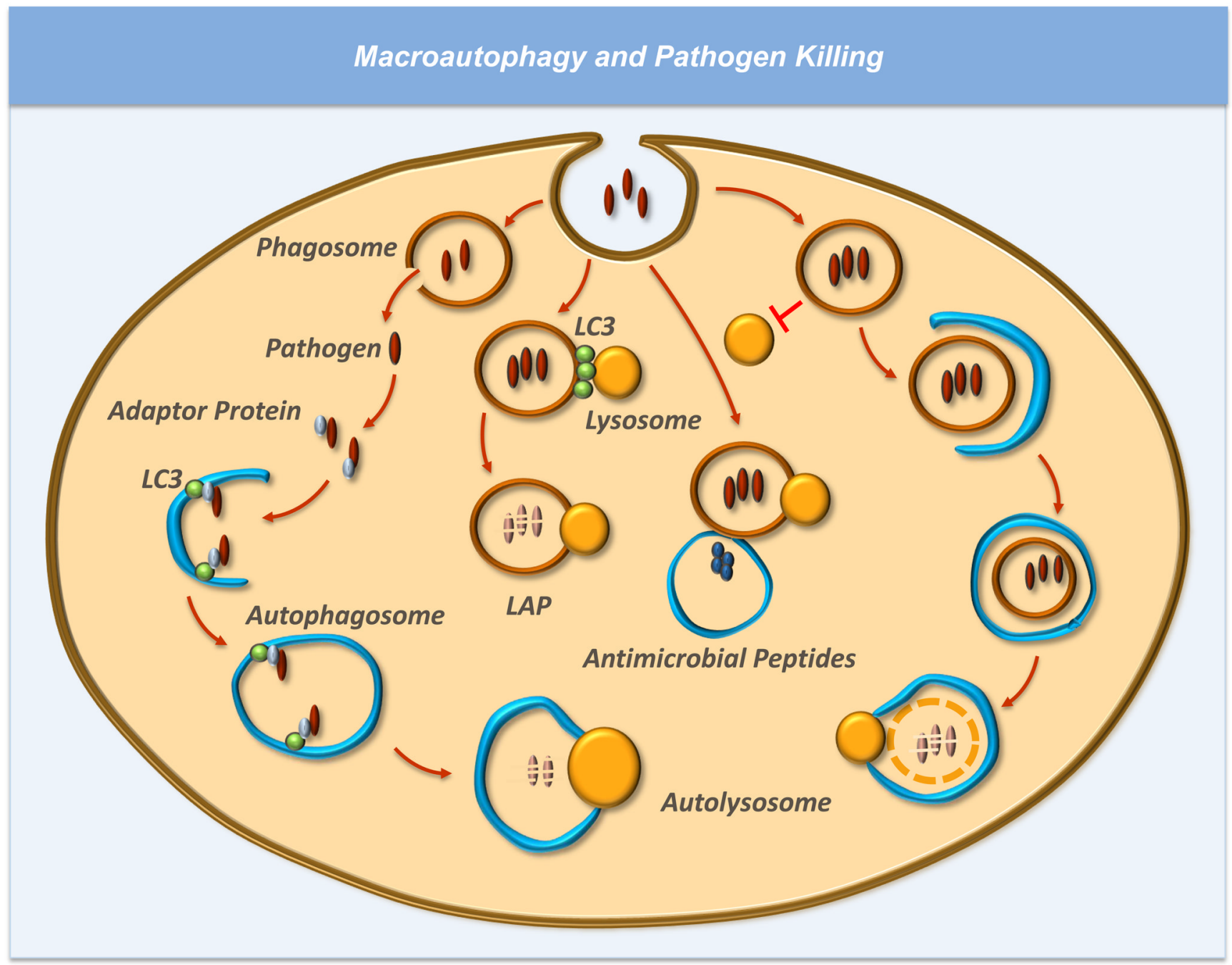

Figure 1. Macroautophagy and Pathogen Killing

Scheme of the mechanisms through which macroautophagy participates in the elimination of pathogens. Pathogens that escape the autophagosome can be modified by ubiquitination and bound by adaptor proteins, such as p62 or Optineurin, that target them to nascent autophagosomes for degradation. It is likely that autophagosome are also able to engulf whole phagosomes, so the cell can bypass virulence mechanisms that prevent phagosomelysosome fusion. Macroautophagy has also been shown to deliver peptides with microbicidal activity to the phagosome to help inactivate and kill pathogens. Finally, LC3 can be recruited to the phagosome membrane where it facilitates phagosome maturation and lysosomal fusion through a process termed LC3-associated phagocytosis (LAP). 


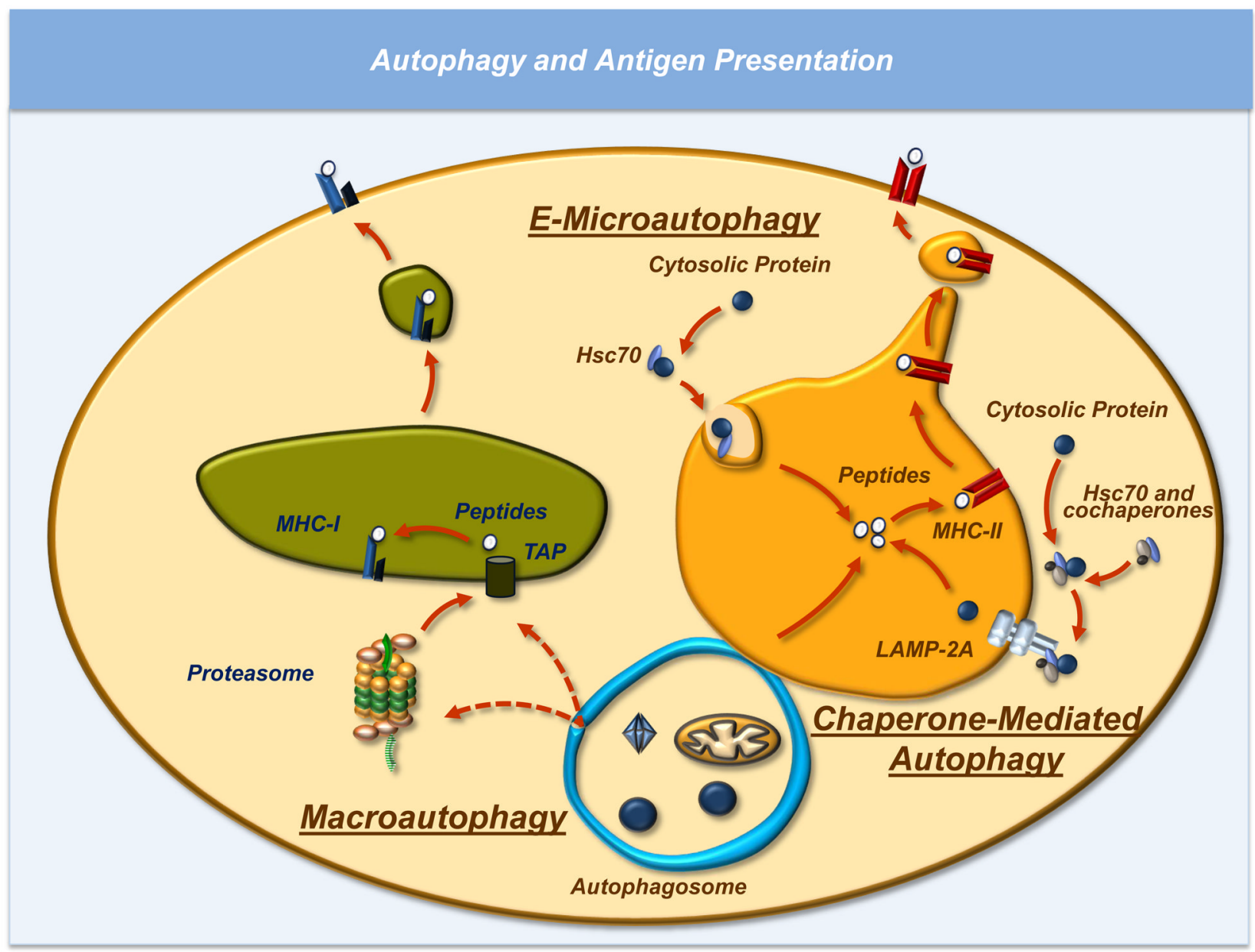

Figure 2. Autophagy and antigen presentation

MHC-II loading compartments have been shown to receive input from 3 different forms of autophagy. Whereas macroautophagy can deliver peptides from pathogens and endogenous proteins and organelles; chaperone-mediated autophagy, chaperone-mediated autophagy and endosomal microautophagy (e-microautophagy) can deliver cytosolic proteins that contain a specific motif recognized by the Hsc70 chaperone. Macroautophagy has also been shown to increase presentation of viral-derived peptides in MHC-I although the precise mechanism through which those peptides reach the class I loading compartment remains to be elucidated. 